\title{
Posttraumatisk stress etter fødsel
}

Kvinnens subjektive opplevelse av fødselen betyr mer for eventuell utvikling av posttraumatisk stressyndrom enn obstetriske komplikasjoner.

Rundt en tredel av alle kvinner opplever det å føde som traumatisk, og opptil $6 \%$ oppfyller kriteriene for diagnosen posttraumatisk stressyndrom i forbindelse med fødselen. Slike fødselsrelaterte traumer er en stor belastning og fører ofte til at kvinnen unngår å bli gravid på ny. Vi har nylig undersøkt hvilke

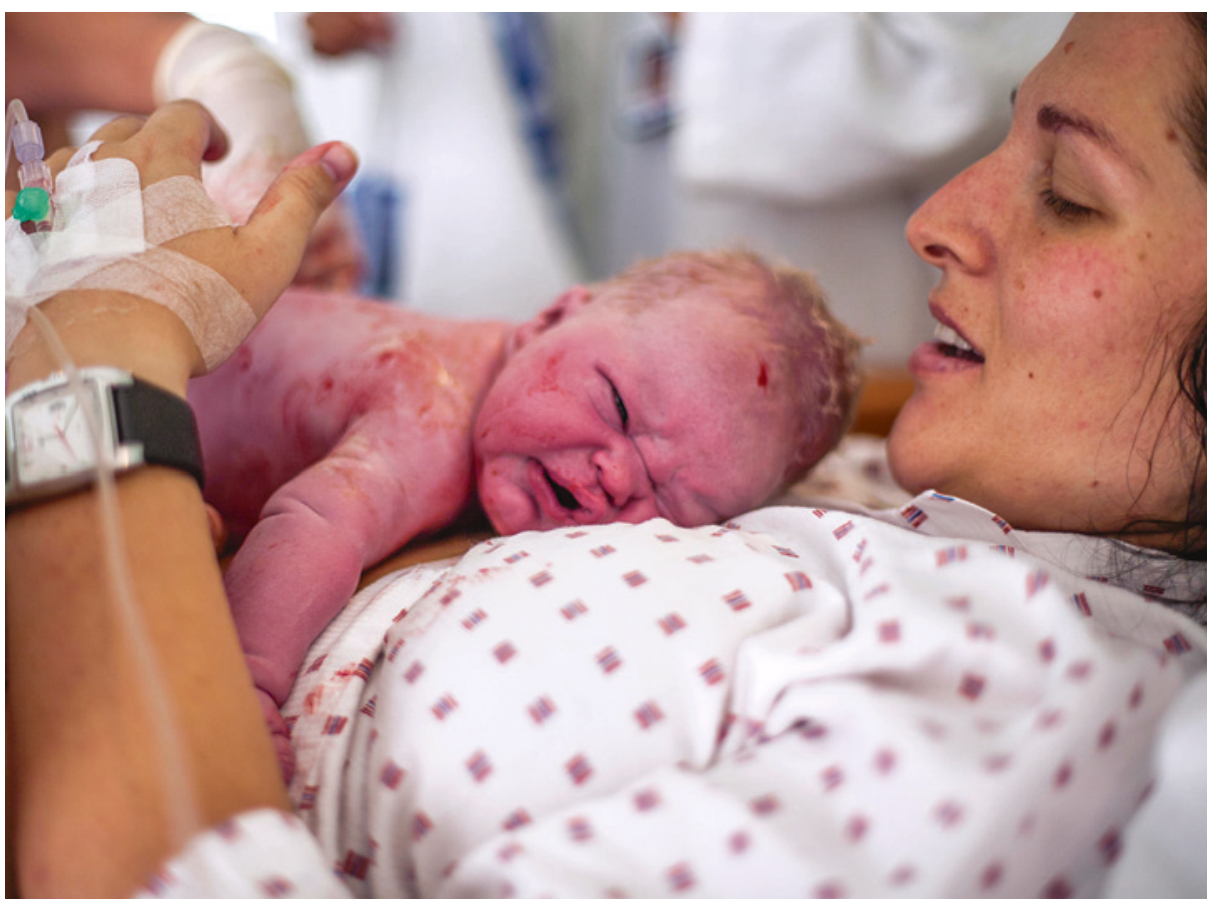

Illustrasjonsfoto: NTB scanpix/Samfoto

\section{Respiratorbehandling av premature}

\section{Behandling med høyfrekvens- respirator til premature ga bedre lungefunksjon og høyere skole- prestasjoner enn behandling med konvensjonell respirator.}

Overlevelsen hos barn født før 28. svangerskapsuke er dramatisk bedret de siste tiårene. Dette skyldes blant annet bruk av surfaktant, lungemodningssprøyter med steroider gitt til den gravide før fødselen og mer teknologisk avanserte respiratorer.

Ved årtusenskiftet ble rundt 800 nyfødte født før 29. uke randomisert til enten høyfrekvent eller konvensjonell respiratorbehandling. Ved 36 ukers alder fant man ingen for- faktorer som har størst betydning for utvikling av posttraumatisk stress etter fødsel $(1,2)$.

Undersøkelsen omfattet nærmere 2000 kvinner som fødte på Kvinneklinikken ved Akershus universitetssykehus. De fylte ut spørreskjemaer under graviditeten, på barselavdelingen og åtte uker etter fødselen. I til- legg ble det innhentet opplysninger fra sykehusets fødejournaler.

Kvinnens subjektive fødselsopplevelse, det vil si hvordan hun selv opplevde fødselen, hadde avgjørende betydning for om hun utviklet posttraumatisk stress eller ikke. Denne opplevelsen hadde mye større betydning enn eventuelle obstetriske komplikasjoner. De objektive hendelsene hadde likevel en viss sammenheng med posttraumatisk stress, ved at slike hendelser kunne påvirke den subjektive fødselsopplevelsen, men den subjektive fortolkningen av fødselsopplevelsen var ikke alltid i samsvar med faktiske obstetriske hendelser.

Obstetriske komplikasjoner kan ikke alltid unngås, men en bedre forståelse av betydningen av kvinnens subjektive fødselsopplevelse kan gi nye muligheter for å forebygge posttraumatisk stress. $\AA$ føle trygghet er en forutsetning for en god fødselsopplevelse, men dette krever god oppfølging og riktig informasjon. Vi mener at nedskjæringer og nedbemanning ved fødeinstitusjoner potensielt kan føre til økt risiko for posttraumatisk stress etter fødsel.

\section{Malin Eberhard-Gran}

Susan Garthus-Niegel

Akershus universitetssykehus og Nasjonalt folkehelseinstitutt

\section{Litteratur}

1. Garthus-Niegel S, von Soest T, Vollrath ME et al. The impact of subjective birth experiences on post-traumatic stress symptoms: a longitudinal study. Arch Women Ment Health 2013; 16: 1-10.

2. Garthus-Niegel S, Knoph C, von Soest T et al. The role of labor pain and overall birth experience in the development of posttraumatic stress symptoms: a longitudinal cohort study. Birth 2014; 41: $108-15$. skjeller i overlevelse eller lungesykdom (1). Da barna var 11-14 år gamle, ble drøyt 300 av dem fulgt opp med lungefunksjonstesting og et spørreskjema om skoleprestasjoner (2).

Spirometri ble brukt som mål på lungesykdom. Selv om forskjellene var små, kom høyfrekvensgruppen best ut for lungefunksjon målt i distale luftveier. De som hadde fått behandling med høyfrekvensrespiratorer, hadde også bedre skoleprestasjoner enn de øvrige.

- Resultatene må tolkes i lys av det som var tilgjengelig respiratorteknologi ved årtusenskiftet. De såkalt konvensjonelle respiratorene er blitt forbedret med tanke på å unngå lungeskade hos altfor tidlig fødte, sier overlege Bjørn Øglænd ved Nyfødtintensivavdelingen, Oslo universitetssykehus, Rikshospitalet. - Man kan derfor ikke på grunnlag av denne studien konkludere med at høyfrekvensbehandling $\mathrm{i}$ dag er bedre enn konvensjonell respiratorbehandling. På den annen side påpekes det med rette at suboptimal respiratorbehandling kan gi negativ påvirkning av hjernens utvikling, sier Øglænd.

\section{Paal H.H. Lindenskov}

Overlege ved Avdeling for anestesiologi,

Oslo universitetssykehus, Rikshospitalet

\section{Litteratur}

1. Johnson AH, Peacock JL, Greenough A et al. Highfrequency oscillatory ventilation for the prevention of chronic lung disease of prematurity. N Engl J Med 2002; 347: 633-42.

2. Zivanovic S, Peacock J, Alcazar-Paris M et al. Late outcomes of a randomized trial of high-frequency oscillation in neonates. N Engl J Med 2014; 370 $1121-30$ Akuttklinikken 